\title{
When Recourses Fail to Protect: Canadian Human Rights Obligations and the Remedies Offered to Foreigners against Immigration Decisions
}

\author{
FRANÇOIS CRÉPEAU*
}

\section{INTRODUCTION}

Canada is one of those countries in which immigration is part of the founding myths.

\section{Concurrent Jurisdictions on Immigration, Save for Entry on the Territory}

The State is, according to traditional international law, the master of its own kingdom. In immigration, this means the right to allow or refuse entrance of an alien on the territory, to impose conditions to her entry, and to expel or deport her from the territory. In Canada, the Constitution Act of 1867 gives concurrent powers over immigration to the Parliament of Canada and the provincial legislatures. However, the control over Canadian borders and the access of non-citizens falls solely under the federal jurisdiction and, therefore, the provinces and the municipalities are not responsible for measures and policies relating to the entry of aliens.

Historically, in the Immigration Act of 1869, the first such Act adopted after Confederation, there was explicit reference to the principle of concurrent jurisdiction over immigration and to the idea that the responsibility for the arrival and settlement of immigrants should be shared and negotiated between federal and provincial jurisdictions. ${ }^{1}$ Section 95 of the Constitution Act of 1867 states that provincial legislatures have powers to make laws with respect to immigration matters in the province. The Parliament of Canada, for its part, may make laws in relation to immigration for Canada as a whole. Any provincial law relating to

\footnotetext{
* Professor of International Law, Canada Research Chair in International Migration Law, Scientific Director, Centre for International Studies (CERIUM), University of Montreal. This paper has benefited from the financial support of SSHRC, FQRSC, VRQ and the programme of Canada Research Chairs. The author thanks Delphine Nakache whose doctoral research on 'The control of irregular migration: how to balance State security concerns with the international obligation to respect the human dignity of involuntarily displaced persons?', inspired some of the thoughts expressed here: an article by François Crépeau and Delphine Nakache, entitled 'The Control of Irregular Migration: Balancing Canada's Security Concerns with International and Charter Human Rights Standards', has been submitted for publication to the Institute for Research on Public Policy, Montreal. The author takes, however, sole responsibility for the content of this paper.
}

${ }^{1}$ Donald Galloway, Immigration Law, Toronto: Irwin Law, 1997, pp. 9-10. 
"immigration shall have effect in and for the province as long and as far only as it is not repugnant to any Act of the Parliament of Canada" (s. 95 Constitution Act of 1867) [my emphasis].

Whether a provincial law was repugnant to a federal law would ultimately be up to a court to decide, but the current judicial trend in cases where legislative jurisdiction overlap is to permit wide latitude to each jurisdiction. It may be predicted that a provincial law relating to immigration that is otherwise constitutional (that is, that did not offend the Canadian Charter of Rights and Freedoms) would likely be found "repugnant" to the federal law only if it were patently contradictory to it.

The separation of the powers on immigration matters is reflected in the current Immigration and Refugee Protection Act (hereinafter IRPA), enacted in June 2002. Its paragraph 8(1) provides for federal-provincial agreements on immigration. Moreover, immigration accounts for a significant part of Canada's population, rate of growth and demographic structure. Therefore it has a strong impact on regional and provincial planning. Section 10(2) of IRPA provides a legal basis for the federal government to consult the provinces regarding the number, distribution and settlement of permanent residents. This provision ensures that the federal government considers regional requirements when developing or amending immigration and settlement policies. As per the other duties and responsibilities pertaining to immigration, the Federal is the jurisdiction in charge. In practice, the province of Québec is the only province with current immigration legislation and with a provincial immigration department (Ministère de l'Immigration et des Communautés culturelles). But even in the case of Québec, the jurisdiction over the borders and security matters remains with the Federal.

Hence, the federal has almost "exclusive" jurisdiction: the federal government makes and administers all laws relating to immigration, except for some in Québec. In this context, the consultations with the provinces are crucial since these are directly and substantially affected by immigration by virtue of its impact on the demand for schools, social services, housing, employment, all provincial matters.

In 1968, Quebec passed its first immigration act, allowing the government to make regulations on a number of matters, including selection criteria, and established an immigration department. The act stresses the goals of integration of immigrants into the francophone majority culture and their acquisition of the French language.

\section{State Actions Limited by Charter}

International law provides that States have the right to control the entry, residence and expulsion of aliens. Any rights of entry or residence possessed by aliens are more limited than those possessed by nationals. A State may be justified in restricting the access of aliens to its territory and in expelling them for security reasons, provided it does not discriminate ${ }^{2}$ and it respects its fundamental laws.

In 1982, the Canadian Constitution was redesigned to include the Canadian Charter of Rights and Freedoms, which identifies and guarantees a set of funda-

${ }^{2}$ See: Chahal v. The United Kingdom (1996) 23 E.H.R.R. 413. 
mental rights. Since 1982, the Canadian Charter provides a national framework of rights that must be respected, in favour of all human beings, be they nationals or refugees, immigrants, foreigners and asylum seekers. ${ }^{3}$ One of the objectives set out in section 3 of IRPA is "to grant, as a fundamental expression of Canada's humanitarian ideals, fair consideration to those who come to Canada claiming persecution" (s. 3(2)c) IRPA).

The Canadian Charter claims to protect individuals only from rights violations by government (s. 32(1) Canadian Charter). The question of determining who is protected by the Canadian Charter's provisions is of clear relevance to immigration decision making. The Canadian Charter itself provides that some rights are vested in citizens, others in permanents residents, and still others in "everyone" and "every individual". As it will be demonstrated in Part I, fundamental rights are not exclusive to Canadian citizens, but also protect foreigners.

\section{The Canadian Immigration Policy}

Canada's immigration law is contained in the Immigration and Refugee Protection Act and the Immigration and Refugee Protection Regulations (hereafter IRPR). Section 3 of IRPA states the objectives of Canada's immigration policy. The major objectives are to increase the number of immigrants, to protect the health and the safety of Canadians, to work in cooperation with the provinces, and to facilitate reunification of families.

There are two principal ways to enter Canada, through a permanent resident visa or a temporary resident visa. Permanent residents are foreigners who wish to establish permanently in Canada as opposed to temporary residents who are in Canada for a limited period of time. Selection of permanent residents is done through family reunification, economic immigration and refugee protection. Canada's immigration is aimed at selecting immigrants in order to answer labour market needs and to integrate immigrants as soon as possible. There are three components to the Canadian immigration programme:

a. The social component where Canada facilitates family reunification and permits the nuclear family unit (spouses, dependent children) to immigrate with principal applicants (s. 3(1)(d) IRPA).

b. The economic component where Canada wants to attract skilled workers and business immigrants who will contribute to the economic life of the country and fill labour market needs (s. 3(1)(c) IRPA).

c. The humanitarian component where Canada reinforces its fulfilment of its international legal obligations by granting permanent residence to government-assisted and privately sponsored refugees (s. 3(2)(b) and (d) IRPA).

The scope of the activities carried out as part of Canada's immigration program is extremely wide. The Immigration and Refugee Board (hereafter the IRB) is the

${ }^{3}$ Canadian Council for Refugees, State of Refugees in Canada, Montreal, 2002, available at: http://www.web.net/ ccr/state.html, p. 2. 
largest administrative tribunal in the country, and holds hearings in immigration matters (s. 173 IRPA) and adjudicates claims to refugee status (s. 170 IRPA).

In addition to the Department of Citizenship and Immigration (hereafter Citizenship and Immigration Canada, or CIC) responsible to run and make immigration policies and the administrative tribunal, other federal departments and agencies are involved in the conducting of the immigration programme. The newly constituted Canadian Borders Services Agency (hereafter CBSA) provides the primary inspections on behalf of CIC for all people wishing to enter the country. The Agency is also involved in other security services given to CIC. Health and Welfare Canada has certain domestic responsibilities relating to the health of refugee claimants and others, and supervises the system of medical checks that is mandatory for all immigrants to Canada and for certain visitors. The Canadian Security and Intelligence Service is responsible for security clearances of prospective immigrants. The Royal Canadian Mounted Police investigates possible violations of the immigration laws.

The immigration program also affects the court system. The Federal Court of Canada $^{4}$ has jurisdiction over most immigration matters, a very litigious field which represents over the half of the Federal Court's workload, at the first level.

Canadian immigration and refugee protection issues present continual challenges and engender almost continual debate for lawmakers, public servants, the media and the public in general. Strict implementation of the immigration rules may force ordinary people hiding in churches in order to try to stave off deportation. Humanitarian gestures, as in the reception of some 5,000 Kosovo refugees in spring 1999, are offset by public distaste for those who arrive "illegally". In addition, the effects of the events of 11 September 2001 continue to echo, and, as we will see in part II, combined with other factors, have an impact on the procedures established towards foreign nationals despite the protection of fundamental rights.

\section{THE CANADIAN IMMIGRATION POLICY}

The Canadian immigration programme has specificities that require some explanation, in order to understand the decline in the rights of foreign nationals. The disparity between the former rights and the new legislation will be emphasized in the third section. Economic immigrants currently represent almost two thirds of the total immigration to Canada. Refugees and protected persons constitute only one tenth of the total and the rest is made of family reunification. ${ }^{5}$ This section will explain the processes for the permanent resident (economic class, family class and protected persons class) and the temporary resident (visitors and permit holders).

\footnotetext{
4 S. 3 of the Federal Court Act, R.S.C. 1985, c. F-7, establishes the Federal Court of Canada as "a superior court of record having civil and criminal jurisdiction for the better administration of the laws of Canada". The Court has jurisdiction over cases by and against the Crown, appeals under numerous federal statutes, disputes in various commercial matters, and the authority to review decisions of federal boards, tribunals and commissions, including decisions of the Immigration and Refugee Board.

5 Citizenship \& Immigration Canada, Annual Report of 2002, Ottawa, 2002.
} 


\section{The Economic Class}

The federal skilled worker class is the most common way to enter Canada as an immigrant. There are four ways of entering legally to Canada for economic purposes: 1) as a skilled worker; 2) as a business immigrant; 3) as a provincial nominee; and 4) as a live-in caregiver. This part will focus on the two major ones, which are the skilled worker class and the business class. Over half of the numbers of the immigrants who obtained their permanent residence are members of the economic class, mostly constituted of skilled workers. This class is prescribed as a class of persons who are skilled and who may become permanent residents on the basis of their ability to become economically established in Canada. ${ }^{6}$ The core element of the selection process of independent immigrants is the point system, according to which points are allocated under a variety of headings with a view of identifying the applicant's capacity to become successfully established in Canada. ${ }^{7}$ The federal government is aiming to increase the number of applicants in this class: it has been attempting in the last years to limit the number of refugees and family members granted permanent residence in Canada, in order to achieve their goal of $60 \%$ of immigration being economic and $40 \%$ non-economic (refugee and family classes). ${ }^{8}$

The member of the skilled worker class becomes a permanent resident at the port of entry after an examination as to the admissibility. If the person is accompanied by family members, the examination must establish that the family members are not themselves inadmissible. ${ }^{9}$ They also have the obligation to make true statements, otherwise they may become inadmissible. IRPA establishes new grounds of inadmissibility based on misrepresentation. ${ }^{10}$ This is of particular importance, because the right to appeal has been eliminated on that ground, as we will see in section III.

The business immigrant's programme seeks to promote economic development and employment by attracting people with venture capital, business acumen and entrepreneurial skills. This program recognized three categories of immigrants: investors, entrepreneurs and self-employed immigrants.

Sections $62-71$ in IRPA give some rights to appeal before the Immigration and Refugee Board to contest negative decisions relating to visas, loss of status or removal orders, to permanent residents. The appeal will be based upon an error of law or fact, the infringement of a principle of natural justice or humanitarian and compassionate considerations. ${ }^{11}$ The effect of the decision is to set aside the previous

\footnotetext{
${ }^{6}$ Québec has its own selection criteria which are similar to the federal system, except as regards language. Under the 1991 Canada-Québec Accord, Québec has control of all settlement and integration programmes for immigrants destined to that province. Québec also sets its own immigration levels (quotas), establishes the financial criteria for sponsors and selects independent immigrants based on the Québec points system. Basically, only the inadmissibility of immigrants (essentially for health or security purposes) remains of federal jurisdiction.

7 S. 75 and 78 IRPR.

${ }^{8}$ Canadian Council for Refugees, Annual Status Report on Refugees and Immigrants, Montreal, 2004, p. 1.

9 S. 85 IRPR.

10 S. 40 IRPA.

11 S. 67(1) IRPA.
} 
decision and to substitute the determination made by the panel. ${ }^{12}$ We can see that visa applicants themselves have no appeal against the refusal decision. Moreover, all foreigners deemed security risks or inadmissible on the ground of misrepresentation have no right to appeal at all. ${ }^{13}$

\section{The Family Class}

Canada's support for family reunification through family sponsorship appeared for the first time during the inter-war period. Helping families reunite in Canada is currently a key objective of Canada's immigration law, as specified in section 3(1)d) of IRPA. Family class immigrants are people sponsored to come or remain in Canada by Canadian citizens and/or permanent residents. This class constitutes the second most important route to come to Canada. ${ }^{14}$ Those relatives who meet the criteria of membership of the family class are thus not required to meet the selection criteria imposed on independent immigrants.

Applications under the Family class for immigration from abroad may be made for a spouse, a common-law or conjugal partner, a dependant child, including a child adopted abroad, a parent, a grandparent, and for a brother, a sister, a niece, a nephew or a grandchild who has been orphaned and is under 18 years of age and is not a spouse or a common-law partner. The dependant child of a sponsored immigrant may be included in that person's application. ${ }^{15}$

Applicants to permanent resident visa application through family class and their family members are subject to medical, criminal and background checks. Successful applicants become permanent residents of Canada, giving the applicant and his or her family members the right to live, study and work in Canada for as long as they remain permanent residents. Finally, sponsors must support their sponsored family members or relatives after they become permanent residents of Canada for a period which varies according to the categories (often one to three years). Usually, sponsors should reside in Canada when making their sponsorship application. ${ }^{16}$

Section 63 of the IRPA allows for appeals by sponsors of members of the family class whose application for permanent resident visa was denied. This distinction emphasizes the fact that the right to appeal is granted only to those who have some connections with Canada. Again, all foreigners deemed security risks or inadmissible on the ground of misrepresentation have no right to appeal at all. ${ }^{17}$

\footnotetext{
12 S. 67(2) IRPA.

13 S. 64 IRPA.

14 For numbers, consult the yearly Annual Report of Citizenship \& Immigration Canada.

15 See s. 12(1) IRPA and ss. 1(3) and 177(1) IRPR.

${ }^{16}$ It is possible for a sponsor who is a Canadian citizen to apply while residing outside Canada, as long as the sponsor resides in Canada when the applicant becomes a permanent resident (art. 130 IRPR).

17 S. 64 IRPA.
} 


\section{The Temporary Resident Class}

Temporary residents possess a lawful permission to come into Canada as a visitor and persons who were granted permit authorizing their entry or stay in Canada are included in this category.

Foreigners wishing to come to Canada as temporary residents must demonstrate that they will respect the conditions that apply to temporary residents. One of these conditions is that they will voluntarily leave at the end of their visit. By definition, a temporary resident is a person who is lawfully in Canada for a temporary purpose. Temporary residents include students, foreign workers and visitors such as tourists. Every temporary resident, except from countries specifically exempted by the IRPR, must obtain a temporary resident visa before arriving in Canada. And a visa is required to everyone who wants to stay in Canada for a period exceeding six months.

Visa officers look at many factors before deciding whether the applicant is a genuine temporary resident, and check especially that the person's intention is not to establish permanently in Canada. In order to do so, visa officers consider the purpose of the visit and the applicant's ties to the home country, including the individual's family and employment situation, and the overall economic and political stability of the home country. The visa officer's assessment is highly discretionary. ${ }^{18}$

Exceptional circumstances may also justify Minister's intervention. The Minister has the power to exempt any foreign national from any application criteria and obligation contained in the Act, and grant the person permanent resident status. Article 25 of the Act gives great power to the Minister without circumcising the scope of that power. ${ }^{19}$ Humanitarian and compassionate considerations must take into account the best interest of the child and public policy interests. Finally, it is also within the Minister's powers to issue a temporary resident permit to a foreign national who is inadmissible or does not meet the requirement of the Act (art. 24 of IRPA). The permit may be cancelled at any time.

Not being a permanent resident or a protected person, temporary residents have virtually no right to appeal immigration decisions taken against them.

\section{The Humanitarian Class}

As a party to the 1951 Geneva Convention relating to the Status of Refugees, Canada has an obligation not to send refugees back to persecution. If a mistake is made in the determination process and a genuine refugee is denied protection and

18 Individuals who apply to come to Canada as temporary residents must also satisfy the visa officer that they are in good health (in some cases a medical examination may be required), they do not have a criminal record, they do not pose a threat to Canada's security, they must have a valid passport or travel document, they have enough money to support themselves and their family members while in Canada, and they will leave Canada voluntarily at the end of their stay. All refugees producing countries are countries for which a visa is required.

19 S. $25 I R P A$ is the most discretionary provision of the Act. 
sent back to persecution, Canada is in violation of its international obligations. In recognition of its international obligations as a party to the 1984 United Nations Convention Against Torture and to the 1966 International Convenant on Civil and Political Rights, Canada, through the IRPA, also offers protection to people in Canada who face a substantial risk of torture, a risk to their life or a risk of cruel and unusual treatment or punishment.

As previously mentioned, in 1989, important changes were made to the former Immigration Act, creating a completely new refugee determination system. The determination of whether a person is a Convention refugee and is thus entitled to receive protection in Canada is made in two distinct situations under the refugee protection part of the legislative scheme: the resettlement program and the refugee claim process. These categories have been kept in IRPA. Visa officers outside Canada have the authority to grant immigrant visas to those whom they identify as Convention refugees seeking resettlement. Resettled refugees may be assisted by the government or sponsored by groups or individuals through the private sponsorship program. Citizenship \& Immigration Canada (CIC) is the federal department responsible for selecting refugees overseas. Alternatively, a person may also make a claim to be a Convention refugee on arrival in Canada or once inside Canada. The Immigration and Refugee Board (IRB) is responsible to determine such claims. Applicants who are resettled in Canada or whose claim is successful become protected persons and must apply with 180 days to get their permanent residence. ${ }^{20}$

The Canadian immigration regime excludes some refugee claimants from having their claim heard. A claim is not eligible if: the claimant has ever before made a refugee claim in Canada; the claimant has been recognized as a refugee in another country and can be returned to that country; the claimant came to Canada through a designated 'safe third country'; the claimant has been determined to be inadmissible on the basis of security, serious criminality, organized criminality or violating international and human rights law.

CIC decides whether or not it is eligible. In past years, very few claimants were found ineligible. ${ }^{21}$ However, the new legislation brought some changes in terms of inadmissibility for security purposes. ${ }^{22}$

Protected persons - defined as persons recognized as Convention refugees, or at risk of being subjected to torture or cruel and unusual treatment or punishment have a right of appeal against removal decisions. ${ }^{23}$ Again, all foreigners deemed security risks or inadmissible on the ground of misrepresentation have no right to appeal at all. ${ }^{24}$

20 See s. 175 IRPR.

21 See: Canadian Council for Refugees, State of Refugees in Canada, Montreal, 2002, available at: http://www.web.net/ ccr/state.html, p. 9.

22 For example, see ss. 117(2), (3), 118, 121, 125 IRPA.

23 S. 63(3) IRPA.

24 S. 64 IRPA. 


\section{Judicial Review}

Any person who wishes to challenge a decision, a determination or an order made under the Immigration and Refugee Protection Act, whether made in Canada or abroad, may make an application to the Federal Court. Leave - i.e. permission - is required for the application to proceed. All applications for leave to apply for judicial review are decided by one judge, normally without personal appearance by the parties. There is no appeal from a decision on a leave application.

The grounds for judicial review are those set out in the Federal Court Act. ${ }^{25}$ They are that the body or person:

- acted without jurisdiction, acted beyond its jurisdiction or refused to exercise its jurisdiction;

- failed to observe a principle of natural justice, procedural fairness or other procedure that it was required by law to observe;

- erred in law in making its decision, whether or not the error appears on the face of the record;

- based its decision on an erroneous finding of fact that it made in a perverse or capricious manner or without regard to the material before it;

- acted, or failed to act, by reason of fraud or perjured evidence; or

- acted in any other way that was contrary to law.

\section{The Review of a Foreigner's Detention}

The IRPA allows, in very specific circumstances, the detention of individuals. The authority to detain in the immigration context exists in Canada to achieve three purposes: to ensure effective removal of inadmissible individuals, ${ }^{26}$ to protect Canadian society from persons considered dangerous, ${ }^{27}$ and to allow for the identification of persons seeking admission. ${ }^{28}$ The grounds for detention are limited to cases where the person poses a danger to the public or may not show up for further proceedings or removal. ${ }^{29}$

Section 57 of IRPA prescribes the review of the detention when the incarceration exceeds 48 hours. The person is brought before an IRB member forthwith for review of the grounds of detention and the Minister establishes a prescribed ground for the detention. If not released by the adjudicator, the person has to be brought before an adjudicator, an independent tribunal, at least once during the seven days immediately following the 48 hours and thereafter at least once during each thirty day period.

${ }^{25}$ Federal Court Act, R.S.C. 1985, c. F-7.

${ }^{26}$ S. 55(1) IRPA.

27 Ss. 3(1)h), 55(1),(2)a) IRPA.

28 S. 55(2)b) IRPA.

${ }^{29}$ S. 55 IRPA. 


\section{THE CONSTITUTIONAL PROTECTION OF FUNDAMENTAL RIGHTS FOR ALL}

The next important question which arises from the analysis is the application of the Canadian Charter. Fundamental rights apply to non citizens. IRPA's objectives also include "that decisions taken under this Act are consistent with the Canadian Charter of Rights and Freedoms, including its principles of equality and freedom" (s. 3(3)d) of IRPA).

The question of determining who is protected by the Canadian Charter's provisions is of clear relevance to immigration decision making. The Canadian Charter itself provides that some rights are vested in citizens, others in permanents residents, such as the mobility rights (s. 6 Canadian Charter), and still others in "everyone" and "every individual". The issue of the ambit of the Canadian Charter has been raised in important cases. In 1985, Singh v. Canada was the first case in which the applicability of the Charter to non-citizens was recognized..$^{30}$ Wilson J. held that section 7 of the Canadian Charter granted rights to every human being who is physically present in Canada and by virtue of such presence amenable to Canadian law. ${ }^{31}$ An important point was then clarified, when defining to whom Charter rights applied: no distinction was made between persons who have been admitted into Canada and those still at the port of entry and. The application of the Canadian Charter to non-citizens outside Canada remains debatable. ${ }^{32}$

Section 24(1) of the Canadian Charter provides that anyone whose rights or freedoms, as guaranteed by the Canadian Charter, have been infringed or denied may apply to a court of competent jurisdiction to obtain such remedies as the court considers appropriate and just in the circumstances. Thus, foreigners whose rights have been affected are able to take active steps to bring a Canadian Charter issue to the Court and seek a remedy under this section.

Three headings of Canadian Charter rights are prominently relevant to immigration law: fundamental freedoms, legal rights and equality rights. The rights included in these sections are not absolute, each being subject to section 1 of the Canadian Charter, which provides that 'the guaranteed rights and freedoms are subject only to such reasonable limits prescribed by law as can be demonstrably justified in a free and democratic society'. If a determination is made that a Charter right has been infringed, then comes the issue of whether the infringement is justifiable under section 1 of the Canadian Charter. Of course, a rigorous test of justifiability under section 1 has been set out by the courts. ${ }^{33}$

The impact of the Canadian Charter on the practice of immigration law has been quite significant: a substantial number of legal challenges on behalf of those who

${ }^{30}$ Singh v. Canada (Minister of Employment \& Immigration) [1985] 1 S.C.R. 177.

31 Singh v. Canada (Minister of Employment \& Immigration) [1985] 1 S.C.R. 177, at 202.

${ }^{32}$ In Ha v. Canada (Minister of Citizenship \& Immigration) [2004] F.C.A. 49, David Matas representing the applicants pleaded the right to a counsel before an immigration officer in a visa post abroad. Unfortunately, the Federal Court of Appeal did not go into the argument of the extra-territoriality of the Canadian Charter.

33 The seminal decision here is that in Oakes v. The Queen [1986] 1 S.C.R. 103. 
have been subject to negative decisions haven been based on Charter grounds. After Singh, which required the restructuring of the refugee determination process, the courts have generally avoided liberal interpretations of the Canadian Charter, and they have built a pattern of decision-making characterized by a rather narrow and restrictive approach to the rights of immigrants and refugee claimants. Moreover, the courts have shown a marked reluctance to scrutinize, to challenge or to reshape the policies of the federal government in this area of decision-making. Thus, although tribunals have progressively recognized rights of foreigners, this has been a slow process.

It is therefore remarkable that some foreigners have been able to challenge such decisions up to the Supreme Court, which has allowed appeals from, for example, a drug dealer threatened with removal to the country of origin where it was likely that the drug cartel would eliminate him, a mentally disabled mother of eight without immigration status in Canada threatened with return to the country of origin without taking into account the interests of her four Canadian children, a murderer threatened with extradition to the United States where he would face death penalty, a Sri Lankan financer of the Tamil Tigers - an organization listed as terrorist - who would face serious harm if returned to Sri Lanka. ${ }^{34}$

\section{Freedom of Association}

Section 2 of the Canadian Charter identifies a list of fundamental freedoms that everyone possesses, including freedom of association. A number of Charter challenges to immigration law have been based on this section, predominantly on the grounds that they impede freedom of association.

In Al Yamani v. Canada, ${ }^{35}$ it was held that part of section 19(1)g) of the former Immigration Act of $1976^{36}$ - proscribing the admission to Canada of members of an organization likely to engage in violent acts that will endanger the safety of people in Canada - was unconstitutional on the ground that, by rendering inadmissible those who were merely members of organizations likely to engage in acts of violence, it violated the applicant's freedom of association. Moreover, the provision was not saved by section 1 of the Canadian Charter because the court found that no rational connection existed between the aim of protecting the safety of people in Canada and the restrictions of the freedoms of individuals who are merely members of an organization. It was also held that the restriction was not proportional to the objective.

${ }^{34}$ See: Pushpanathan v. Canada (Minister of Citizenship and Immigration) [1998] 1 S.C.R. 982; Baker v. Canada (Minister of Citizenship and Immigration) [1999] 2 S.C.R. 817; United States v. Burns, [2001]

1 S.C.R. 283; Suresh v. Canada (Minister of Citizenship and Immigration) [2002] 1 S.C.R. 3.

${ }^{35}$ Al Yamani v. Canada (Solicitor General) [1996] 1 F.C. 174 (T.D.).

36 "Member of an organization likely to engage in violent acts." This offence is now found under s. 34(1) IRPA. 


\section{Mobility Rights}

There is a right to freedom of movement given to every individual in Canada: the right to take up residency anywhere in Canada is guaranteed by section 6 of the Canadian Charter. Immigrants tend however to settle disproportionately in Canada's large urban centres: in 2000, close to $50 \%$ of all immigrants settled in Toronto and $30 \%$ in Montréal and Vancouver. ${ }^{37}$ Therefore, the immigrant may initially state that she is going to live in Québec, for example, but still has the right to leave and move somewhere else in Canada. There may still be some requirements with respect to the location of the job that is to be fulfilled by some immigrants.

\section{Legal Rights}

The rights protected under section 7 of the Canadian Charter have been the object of more judicial analysis than any other. This is especially true in the immigration field. The section reads as follows: "Everyone has the right to life, liberty and security of the person and the right not to be deprived thereof except in accordance with the principles of fundamental justice" [my emphasis].

This statement raises several questions in relation to immigration issues. ${ }^{38}$ What procedures are required by the principles of fundamental justice? What factors are to be taken into account when deciding if these factors are consistent with these principles? Do the principles of fundamental justice prohibit or require access to decision-makers? Does an individual have a right not to be excluded from the refugee determination process? Does a person have a right to an appeal from a negative decision? What is the substantive content of the right to life, liberty and security of the person? Are these rights infringed by an order excluding or removing a person from Canada? Are they infringed by an order against a family member of whom one is dependant, such as a parent or a spouse? Since 1985, the Courts have tried to answer these questions and to limit the scope of section 7, but nevertheless always recognized its application to foreign nationals.

The procedural requirements of the principle of fundamental justice are generally analyzed according to the administrative law principles of procedural fairness. The central issues are:

- whether or not the procedures are adequate to allow a full presentation of the case and a proper determination of the issues;

- where a hearing has been granted, whether adequate notice of its nature has been given;

- whether there has been sufficient disclosure of evidence;

- whether adequate opportunity to respond to negative evidence has been given;

- whether adequate legal representation and interpretation is available; and

- whether there have been unjustifiable delays in proceeding.

${ }^{37}$ Citizenship and Immigration Canada, Facts and Figures 2002, Ottawa.

38 The following questions are taken from: Donald Galloway, Immigration Law, Toronto: Irwin Law, 1997, p. 57. 


\section{Refugee Determination Process and Fundamental Justice}

In Singh v. Canada, the Supreme Court of Canada held that the refugee determination process did not meet the procedural requirements of section 7 of the Canadian Charter, since it did not provide claimants with an oral hearing during which they could state their case. The Singh decision recognized that refugee claimants were entitled to fundamental justice under the Canadian Charter.

The issue at stake was whether the then current procedure for determining refugee claims unjustifiably infringed upon the claimants' rights under section 7 of the Canadian Charter. Wilson J., for the majority, observed that the claimants, not being citizens or permanent residents of Canada, had no right to enter and remain in Canada, but she held that this lack of status did not bar their challenge of the procedure by which their claim to be a Convention refugee was to be determined. The challenge was based on the fact that no oral hearing was afforded to them. Wilson J. stated that

Given the potential consequences for the appellants of a denial of the status if they are in fact a person with a "well-founded fear of persecution", it seems to me unthinkable that the Charter would not apply to entitle them to fundamental justice in the adjudication of their status. ${ }^{39}$

Wilson J. concluded that the principles of fundamental justice must be respected when the issue of genuineness is being determined. She insisted that where issues of credibility were likely to arise, as they often are in refugee cases, the principles of fundamental justice required that an oral hearing take place.

This decision prompted extensive reform to the determination process. The Immigration Act of 1976 was amended to include access criteria that a claimant must meet before being allowed to make a refugee claim. The Immigration and Refugee Board (IRB) was established in 1989 and then significantly reshaped in 1992.

As will be seen, the impact of Singh has been diluted by legislation and recent cases.

In Nguyen v. Canada, the applicant sought judicial review of a decision that he was ineligible to have his claim considered by the Refugee Division on the ground that he had committed a serious offence and the minister had certified that he was a danger to Canada. ${ }^{40}$ The challenge was based partly on the fact that the procedure by which the minister issued a certificate did not allow for an oral hearing. The application was denied. Marceau J.A. distinguished Singh on the ground that, under the law at the time, Singh had a right to make a refugee claim, while the applicant in this case had not been granted a right to seek refugee status. He also concluded without analysis that when eligibility to make a claim is being determined, there is no need to have an oral hearing. This seems to clearly contradict the Singh decision where Wilson J. clearly stated that whether or not one has a right or a privilege at stake should not be a determining factor in recognizing that person their right to be

39 Singh v. Canada (Minister of Employment \& Immigration) [1985] 1 S.C.R. 177, at 210.

${ }^{40}$ Nguyen v. Canada (Minister of Employment \& Immigration) [1993] 1 F.C. 696 (C.A.). 
heard. ${ }^{41}$ The consequences of the deportation on the individual should lead the analysis on whether or not an oral hearing should be granted.

Another case was distinguished from Singh by the Federal Court. In McAllister v. Canada, the Minister had determined that it was contrary to the public interest to allow the applicant to make a refugee claim on the ground that there was reason to believe that he was a member of a terrorist organization. ${ }^{42}$ No oral hearing had been granted to the applicant before this decision was reached. Singh was distinguished by McKay $\mathrm{J}$. on the ground that no credibility issue was at stake and that a process which allowed only written submissions to be made was sufficient to meet the requirements of section 7 of the Charter.

The Supreme Court of Canada, in Chiarelli v. Canada, considered the constitutionality of a deportation order against a permanent resident who had been in Canada for eleven years, since the age of fifteen..$^{43}$ The order had been issued on the ground that he had committed a serious criminal offence. At the Federal Court of Appeal, the deportation procedures to which Chiarelli had been subjected, which involved the issuance of a security certificate, had been found to be unconstitutional because they were in violation with section 7 of the Charter. The latter decision was reversed by the Supreme Court of Canada. Sopinka J. held that it was not necessary to focus on the question of whether the appellant has been deprived of his right to life and security since there had been no breach of fundamental justice. $\mathrm{He}$ concluded that the procedures followed by the Security Intelligence Review Committee were consistent with the principles of fundamental justice. Although a part of the hearing had been conducted in camera, Chiarelli had been provided with a summary of evidence sufficient to allow a response. Sopinka J. notes that:

[While] an individual has an interest in a fair procedure [...] the state also has a considerable interest in effectively conducting national security and criminal intelligence investigations and in protecting police sources [...] The CSIS [Canadian Security Intelligence Service] Act and Review Committee recognize the competing individual and state interests and attempt to find a reasonable balance between them. ${ }^{44}$

Sopinka J. has engaged in the balancing of fundamental justice against state interests when determining the content of a right to fundamental justice. This decision shows a significant shift after Singh.

Later the Federal Court reiterated the Supreme Court's position in Chan v. Canada ${ }^{45}$ where Chiarelli was followed. In Chan, the applicant challenged section 82.1 of the former Immigration Act of 1976, which allowed for non-disclosure of confidential information to an applicant seeking judicial review of a visa's officer decision on grounds of section 7 of the Canadian Charter. Cullen J. rejected the challenge, stating that:

${ }^{41}$ Singh v. Canada (Minister of Employment \& Immigration) [1985] 1 S.C.R. 177, at 210.

${ }^{42}$ McAllister v. Canada (Minister of Citizenship \& Immigration) [1996] 2 F.C. 190 (T.D.).

${ }^{43}$ Chiarelli v. Canada (Minister of Employment \& Immigration) [1992] 1 S.C.R. 711.

${ }^{44}$ Chiarelli v. Canada (Minister of Employment \& Immigration) [1992] 1 S.C.R. 711, at 744-745.

${ }^{45}$ Chan v. Canada (Minister of Citizenship \& Immigration) [1996] 3 F.C. 349 (T.D). 
While fundamental justice demands a fair procedure, its does not demand a perfect system of full disclosure and full oral hearing in every case. These principles of fundamental justice are not immutable, but can vary according to the context in which they are invoked. In the context of section 82.1(10), the secret information is carefully reviewed by a judge of this Court and he or she must consider whether the information could be revealed to the person concerned. While the applicant does not get a summary of the confidential evidence, as in the case of a certificate filed under section 40.1 of the Immigration Act, she is told why she is being denied admission to Canada. ${ }^{46}$

The new Act restates the same rule in its section 87. These two examples show the fragile status of the foreigner's right to fundamental justice.

The idea that principles of fundamental justice can vary according to the context was also emphasized in other cases. For example, the court held that the principles of fundamental justice do not require that a person be provided with counsel at a port of entry interview when notes were being taken by a senior immigration officer. ${ }^{47}$ These notes were later used as evidence during an inquiry into whether there was a credible basis to the applicant's refugee claim. Iacobucci J., from the Supreme Court of Canada, held that the grant of counsel at this early stage would change its nature from a process to determine the appropriate procedures into a mini-inquiry just as complex and prolonged as the inquiry provided for under the Act and Regulations. Since this decision, broader powers have been granted to senior immigration officers at port of entry, including the power to determine the eligibility of refugee claimants to have their claim heard by the IRB.

\section{THE REDUCTION OF THE RIGHT TO A REMEDY UNDER CANADIAN IMMIGRATION LAW}

Permanent residents are, on paper, on an equal footing with Canadian citizens. The rights granted to Canadian citizens are also provided to the permanent residents except for the right to vote and be elected, the right to enter and remain in Canada and the right to minority language education (ss. 3, 6, 23 Canadian Charter respectively). Armed forces and employment related to Canadian security are also limited to Canadian citizens.

The permanent residence is the last step before acquiring Canadian citizenship: unless one commits a crime, obtaining citizenship after three years of permanent resident status is almost automatic. The idea is to integrate foreigners who intend to stay permanently in Canada as soon as possible. It is derived from the Canadian immigration philosophy. However, as we will see, there are discrepancies in the remedies offered to permanent residents and more restrictive access for foreign nationals who have no status yet in Canada.

${ }^{46}$ Chan v. Canada (Minister of Citizenship \& Immigration) [1996] 3 F.C. 349 (T.D), at 364-365.

${ }^{47}$ See: Dehghani v. Canada (Minister of Employment and Immigration) [1993] 1 S.C.R. 1053. 


\section{Appeals Have Been Replaced by Judicial Review}

In Canadian immigration law, since the early 1990s, most forms of appeal previously available to foreigners have been eliminated. Appeals allow the applicant to contest the validity of adverse decisions, on legal and factual grounds, and to obtain a new decision by a new decision-maker. In Canada, as mentioned before, the immigration process produces numerous decisions. The complexity of the stories and the level of factual knowledge required in order to process application mean that the decision-makers must develop a great level of expertise. An expert quasi-judicial body, such as the Canadian Immigration and Refugee Board, can allow for the development of such expertise. But it remains that, since the nature of the decisions made on immigration cases is administrative and since they are most often based on the interpretation of complex factual evidence, appeals are crucial.

Judicial review remains available, but only with leave (or permission) from the Court and essentially only on legal issues. For example, a rejected refugee claimant can apply to the Federal Court for leave to seek judicial review. ${ }^{48}$ However, such leave is rarely granted and the Court does not provide a reason when it denies leave. From 1998 to 2004, 89\% of applications to the Federal Court for judicial review of refugee claim determinations were denied leave. If we compare the number of applications granted leave during this period (under 4,000), with the number of claims refused by the Immigration and Refugee Board during this period (just under 87,800 ), we find that only $4 \%$ of refused claimants had the opportunity to have the decision against them reviewed by the Federal Court. ${ }^{49}$

Furthermore, when a claimant is granted leave by the Federal Court, factual mistakes will generally not be corrected since the Court will not review the factual analysis, unless it was wholly unreasonable. ${ }^{50}$ Reviewable mistakes include mistakes such as the decision-maker failing to take into consideration relevant evidence or drawing unreasonable conclusions from the evidence. If the original decisionmaker considered all the evidence in a reasonable way, but reached the wrong conclusion, the Court will not intervene. Thus, judicial review does not review the merits of the case. It is particularly difficult to get a decision overturned when it hinges on the credibility of the claimant's testimony, since the Court will usually say that the decision-maker who heard the claimant is best placed to judge whether they were credible.

\footnotetext{
48 S. 77 IRPA.

${ }^{49}$ Canadian Council for Refugees, The Refugee Appeal: Is No One Listening?, Montréal, 2005.

${ }^{50}$ The grounds for judicial review, set out in s. 18.1(4) Federal Court Act, are that the tribunal whose decision is being challenged: (a) acted without jurisdiction, acted beyond its jurisdiction or refused to exercise its jurisdiction; (b) failed to observe a principle of natural justice, procedural fairness or other procedure that it was required by law to observe; (c) erred in law in making a decision or an order, whether or not the error appears on the face of the record; (d) based its decision or order on an erroneous finding of fact that it made in a perverse or capricious manner or without regard for the material before it; (e) acted, or failed to act, by reason of fraud or perjured evidence; or (f) acted in any other way that was contrary to law.
} 
A decision can be wrong and, if it does not contain the kind of mistake subject to review by the Federal Court, which is the only forum where a negative refugee determination can be overturned, it is final.

\subsection{Permanent and Temporary Residents}

Since the implementation of the new legislation in 2002, no appeal is now available to a sponsor (it is the same with visa holders and Convention refugees) in the following two situations: ${ }^{51}$ (1) where a security certificate has been signed and where the certificate has been determined to be reasonable by a federal court judge; and (2) where the minister is of the opinion that the person is a danger to the public and the person is also inadmissible under specified paragraphs of section 19 of the former Act ${ }^{52}$ or of sections 34 and 35 of IRPA.

Even Canadian sponsors of foreigners found to be inadmissible on grounds of security, violating human or international rights, serious criminality or organized criminality, have been deprived of any right to appeal..$^{53}$ Moreover, IRPA specifies that no more appeal is possible with respect to a decision based on a finding of inadmissibility on the grounds of misrepresentation. ${ }^{54}$

\subsection{Refugees}

For refugees who are rejected in the resettlement program, there is no right of appeal. For refugee claimants in Canada, the situation could be different.

The IRPA created a Refugee Appeal Division (RAD) where refugee determinations could be reviewed on questions of law, facts or mixed questions of law and facts. ${ }^{55}$ The RAD is a direct response to a longstanding criticism of the Canadian refugee determination process, one of the few of the Western world to lack an appeal. ${ }^{56}$ The appeal approved by Parliament is however a modest one, limited to a paper review. ${ }^{57}$ This new recourse balanced the reduction of the number of board members hearing the claimant's initial application from two to one.

However, when the government implemented the new legislation in June 2002, it did not create the Refugee Appeal Division, maintaining this decision for an indeterminate period of time..$^{58}$ The government has failed to this day to implement the Refugee Appeal Division, despite repeated promises by the Minister to do it by 2003. The government has repeatedly justified its failure to respect the law by reference

\footnotetext{
51 Ss. 64 and 326(2) IRPA.

52 Ss. 77(3.01) and 19(1)(c), (c1), (c2), or (d) Immigration Act 1976.

53 S. 64 IRPA. See also: François Crépeau, Estibalitz Jimenez. 2004. "Foreigners and the Right to Justice in the Aftermath of 9/11". International Journal of Law and Psychiatry. 27(6):609-26.

$54 \mathrm{~S}$. 64(3) IRPA. There is a right to appeal if the foreign national in question is the sponsor's spouse, common-law partner or child.

55 S. 171 IRPA. Not in force yet.

${ }^{56}$ Canadian Council for Refugees, The Refugee Appeal: Is No One Listening?, Montreal, 2005, p. 10.

57 Ss. 110, 111 IRPA.

${ }^{58}$ Canadian Council for Refugees, The Refugee Appeal: Is No One Listening?, Montreal, 2005, p. 1.
} 
to management concerns such as backlogs, number of claimants and length of processing times, and resources constraints. ${ }^{59}$

The management of immigration files is certainly made more efficient, but human rights protection has been radically diminished, as unanimously observed by the Inter-American Commission on Human Rights, UNHCR and CAT respectively in 2000, 2002 and 2004. ${ }^{60}$ As Prof. Dyzenhaus rightly points out:

The Canadian government is joining the ranks of Western governments which are using the political context created by $9 / 11$ to renege on a general commitment to the rule of law. This fact is most marked in the area of immigration and refugee law. Canada is now in flagrant violation of one of the central pillars of the rule of law, the right of access to an independent court to test the legality of decisions affecting basic rights. Judicial review of such decisions is available, but only on leave, which is infrequently granted. That this is an inadequate safeguard has been recognised through a legislative promise to establish a Refugee Appeal Division, a promise which the government refuses to implement. In persisting with this refusal, the government exhibits the two faced stance which is so depressingly common these days whereby governments maintain the facade of the rule of law without delivering its substance. ${ }^{61}$

\section{Legal Aid Remains Inadequate}

The Constitution Act of 1867 provides for the different levels of government and their jurisdiction. Immigration, as we saw, is an area of mixed jurisdiction but is mainly dealt with by the federal government. For matters falling under "property and civil rights" (s. 92(13) Constitution Act of 1867), such as legal aid, the Provinces are exclusively responsible for developing and managing the policies, and they make appropriate decisions on how to run programs with respect to this matter.

Based on the Canadian Charter, the refugee determination process is quasi-judicial and each refugee claimant has the right to a hearing with full interpretation and the right to counsel (see Singh above). However, it has never been deemed important, in Canadian law and policy, to provide sufficient legal aid to help refugees prepare their case. Although the refugee determination system is of federal jurisdiction, legal aid in such matters has been left to the provincial legal aid schemes without insuring some equalization.

In Ontario, the average legal aid fee for a refugee determination case is still over CAN\$1500. In Quebec, it is CAN\$455 (for one asylum seeker, without any detention hearing, before judicial review), which represents 3 hours of work, if an interpreter is not required. In British Columbia, legal aid for refugee determination cases was totally eliminated in June 2003, although further negotiations resulted in the re-

59 Citizenship \& Immigration Canada, News Release, 29 April 2002.

${ }^{60}$ Canadian Council for Refugees, The Refugee Appeal: Is No One Listening?, Montreal, 2005.

${ }^{61}$ Canadian Council for Refugees, The Refugee Appeal: Is No One Listening?, Montreal, 2005, p. 3. 
introduction of a limited service in March 2004. The importance of legal aid in criminal cases has been underscored, in order to help accused persons to defend themselves properly and ensure the legitimacy of any subsequent guilty verdict. If the worst mafia boss has a right to legal aid, why is it that, in refugee cases, when the consequences of an erroneous decision can be death, torture or prison, the provision of legal aid is not thought equally important? ${ }^{62}$

The Supreme Court of Canada examined the issue of the right to counsel as a facet of the principles of fundamental justice in Dehghani v. Canada. ${ }^{63}$ According to Singh, the procedures set out in the former Immigration Act must "provide an adequate opportunity for a refugee claimant to state his case and know the case he has to meet". ${ }^{64}$ It is this constitutional requirement which is the basis for a right to funded counsel for refugee claimants. Moreover, federal cost-sharing arrangements ${ }^{65}$ covering refugee claimants indicates that, in all cases, refugee claimants need counsel to assist them to adequately present their case.

Since Dehghani, there has been no Canadian jurisprudence resolving the issue with respect to refugee claimants. However, cases in the criminal and child protection law contexts offer some suggestions for criteria which may be applied. ${ }^{66} \mathrm{~A}$ similar set of criteria (the level of difficulty of the claim, the effect of ministerial participation and the characteristics of the claimant) should be used to form the basis of an administrative structure to ensure funded counsel, for all impecunious refugee claimants throughout Canada are the principal elements to justify the right to funded counsel.

\section{Security Certificates Trump the Right to Justice}

In addition to objectives relating to the facilitation of the admission of immigrants and the protection of refugees, an important objective is to maintain and protect the health, safety and good order of Canadian society. In furtherance of this objective, sections 34 to 42 of IRPA lists classes of inadmissible foreign nationals. Sections 34,35 and 36 describe individuals involved in espionage, subversion of democratic governments or terrorism.

62 See: François Crépeau, Estibalitz Jimenez. 2004. "Foreigners and the Right to Justice in the Aftermath of 9/11". International Journal of Law and Psychiatry. 27(6):609-26; John Frecker, Pierre Duquette, Don Galloway et al. 2002. "Representation for Immigrants and Refugee Claimants". Study Report. Accessed 23 March 2005. http://canada.justice.gc.ca.

${ }^{63}$ Dehghani v. Canada (Minister of Employment and Immigration) [1993] 1 S.C.R. 1053.

${ }^{64}$ Singh v. Canada (Minister of Employment and Immigration) [1985] 1 S.C.R. 177, at 213, 226-227 (Wilson J.).

${ }^{65}$ For more details on the funding programme, see: Justice Canada, Report of the Department of Justice Canada on the Legal Aid programme, Ottawa, 2001, available at: http://canada.justice. gc.ca/en/ ps/eval/reports/01/legal_aid/legal_aid_1.html.

66 See: Howard v. Stony Mountain Institution, [1984] 2 F.C. 642; Rodriguez v. British Columbia (Attorney General) [1993] 3 S.C.R. 519; R. v. Rowbotham [1994] 2 S.C.R. 463; New Brunswick (Minister of Health and Community Services) v. G. (J.) [1999] 3 S.C.R. 46; Winters v. Legal Services Society [1999] 3 S.C.R. 160; Canada (Minister of Citizenship and Immigration) v. Jaballah [2003] F.C.J. No. 1274 (C.A.); United States of America v. Akrami [2001] B.C.J. No. 174. 
Following the events of 9/11, the Canadian Anti-terrorism Act, adopted on 24 December 2001, amended the Criminal Code and created new offences related to terrorism. Canada is not the only country which has put in place mechanisms against terrorism actions, especially after $9 / 11 .{ }^{67}$ However, as will be demonstrated, the stress put on the fear factor took such place that the humanitarian tradition was put aside and the human rights acquis infringed.

\subsection{Terrorism as a Ground for Detention and Removal}

In 1988, the former Immigration Act 1976, was amended ${ }^{68}$ to include two distinct schemes governing the removal from Canada of persons with criminal or terrorist backgrounds or individuals inclined to serious criminality actions. One regime applied to permanent residents ${ }^{69}$ and another one governed other foreigners..$^{70}$ In its section 38.1, it enumerated the objectives for enacting the new provisions:

a) to enable the Government of Canada to fulfil its duty to remove persons who constitute a threat to the security or interests of Canada or whose presence endangers the lives or safety of persons in Canada;

b) to ensure the protection of sensitive security and criminal intelligence information; and

c) to provide a process for the expeditious removal of persons found to be members of an inadmissible class referred to in section 39 or 40.1 .

IRPA stipulates that the same procedures prescribed for foreign nationals will be applicable to permanent residents. ${ }^{71}$ However, the detention scheme applicable remains different. The Canadian Border Services Agency (CBSA) and the Solicitor General may issue a warrant for the arrest and detention of a permanent resident who is named in the certificate if they have reasonable grounds to believe that the permanent resident is a danger to national security or to the safety of any person or is unlikely to appear at a proceeding or for removal. If the detention is required, IRPA provides for a review after 48 hours and is brought back before a judge at least once in the six-month period following each preceding review and at any other

\footnotetext{
${ }^{67}$ As numerous countries of the world, Canada is also a party to the twelve anti-terrorism conventions, among which: 1963 Convention on Offences and Certain Other Acts Committed on Board Aircraft; 1970 Convention for the Suppression of Unlawful Seizure of Aircraft; 1973 Convention for the Suppression of Unlawful Acts against the Safety of Civil Aviation; 1971 Protocol for the Suppression of Unlawful Acts of Violence at Airports Serving International Civil Aviation; 1977 Convention on the Prevention and Punishment of Crimes against Internationally Protected Persons, including Diplomatic Agents; 1979 Convention against the Taking of Hostages; 1980 Convention on the Physical Protection of Nuclear Material; 1998 International Convention for the Suppression of Terrorist Bombings.

68 An Act to Amend the Immigration Act, 1976 and the Criminal Code in consequence thereof, Section 40.1 was amended by An Act to Amend the Immigration Act and other Acts in consequence thereof, proclaimed in force February 1, 1993.
}

${ }^{69}$ Ss. 39, 40 Immigration Act, 1976.

70 Ss. 40.1, 40.2 Immigration Act, 1976.

71 S. 55(1) IRPA. 
times that the judge may authorize..$^{72}$ Interestingly, the Federal Court, in Jaballah, ${ }^{73}$ had concerns with the detention of a foreigner who was in detention in solitary confinement, since mid-August 2001. A motion to preserve Mr. Jaballah's fundamental rights was heard by the Court on April 11th, 2003. Meanwhile, no final decision on his application to the Minister has been communicated to the Court, as has been expected in accordance with the IRPA and the IRPR. The motion was based on the principle of abuse of process and claiming Charter interests. In MacKay J. opinion, the "delay in determining Mr. Jaballah's application for protection while he remains in detention, with no reasonable forecast of when that decision will be made, constitutes abuse of process in this case". ${ }^{74}$

The security certificate regime offers an alternative process for the removal of foreign nationals who are considered to be inadmissible to Canada for serious security reasons. In fact, the regime overrides other provisions of the legislation relating to detention and judicial review. Detention and removal of foreign terrorists, whether currently active or professed to be retired, are considered necessary for the safety of the public in Canada and for the security of Canada. The Federal Court stated that "individuals who engage in terrorism are very dangerous, frequently fanatical in their beliefs, have little regard for human lives including their own and are transient". ${ }^{75}$ Even though the issuance of a certificate results in the arrest and detention of the person involved, this detention is not imposed for punishment. Rather, it is intended to provide preventive detention to ensure the expulsion of the individual and to safeguard the Canadian public.

The most recent case on security certificate from the Supreme Court of Canada is the case of Suresh.$^{76}$ Mr. Suresh is a Sri Lankan citizen of Tamil descent, and an executive member of the Liberation Tigers of Tamil Eelam (LTTE), a Sri Lankan organization listed as a terrorist organization. In Canada, evidence showed that he had been involved, under cover of the World Tamil Movement, in raising funds to support the activities of the LTTE. It was on the basis of a Security Intelligence Report, prepared by the Canadian Security and Intelligence Service, that Mr. Suresh was found inadmissible as "being someone who there are reasonable grounds to believe has engaged in terrorism, and is or was a member of an organization that there are reasonable grounds to believe is or was engaged, or will engage, in terrorism". ${ }^{77}$ In fall 1995, the Solicitor General of Canada and the Minister of Citizenship and Immigration signed a security certificate under section 40.1 of the Immigration Act $1976 .^{78} \mathrm{Mr}$. Suresh was arrested in October 1995, and detained: the authorities initiated deportation proceedings. The appeal to the Supreme Court was heard prior to 11 September 2001, but the decision rendered subsequent to those

${ }^{72}$ S. 83 IRPA.

${ }^{73}$ Jaballah (Re) (T.D.) [2003] 4 F.C. 345.

${ }^{74}$ Jaballah (Re) (T.D.) [2003] 4 F.C. 345, para. 28. See also para. 14, 28 to 30.

${ }^{75}$ Ahani v. Canada, [1995] 3 F.C. 669; aff'd Ahani v. Canada, [1996] F.C.J. No. 937 (F.C.A.), leave to appeal dismissed on July 3, 1997 by the Supreme Court of Canada.

${ }^{76}$ Suresh v. Canada (Minister of Citizenship and Immigration) [2002] 1 S.C.R. 3.

77 Ss. 19(1)(e)(iv)(c), 19(1)(f)(ii), and 19(1)(f)(iii)(B) Immigration Act, 1976.

${ }^{78}$ Now s. 77 IRPA. 
events and after the coming into force of the Canadian Anti-terrorism Act. The Court had to decide whether expelling a suspected terrorist to a country where he faced the risk of torture violated the principle of fundamental justice in contravention to section 7 of the Canadian Charter. From a domestic perspective, the Supreme Court recognized that Canada has a legitimate and compelling interest in combating terrorism but is also committed to fundamental justice:

On the one hand stands the manifest evil of terrorism and the random and arbitrary taking of innocent lives, rippling out in an ever-widening spiral of loss and fear. Governments, expressing the will of the governed, need the legal tools to effectively meet this challenge. (...) On the other hand stands the need to ensure that those legal tools do not undermine values that are fundamental to our democratic society - liberty, the rule of law, and the principles of fundamental justice - values that lie at the heart of the Canadian constitutional order and the international instruments that Canada has signed. In the end, it would be a Pyrrhic victory if terrorism were defeated at the cost of sacrificing our commitment to those values. Parliament's challenge is to draft laws that effectively combat terrorism and conform to the requirements of our Constitution and our international commitments. $^{79}$

The Supreme Court then considered the same question in light of international standards and confirmed the absolute prohibition of torture and the principle of nonrefoulement "even where national security interests are at stake" ${ }^{80}$ By holding that consideration must be given not only to Canadian experience and jurisprudence, but also to international law, the Supreme Court established that courts have to use standards of international human rights law defined in treaties and custom to inform Charter interpretation and, in particular, to serve as evidence of the principles of fundamental justice. In Suresh, however, the Supreme Court recognized the dilemma facing the judiciary in integrating international treaty standards which are not binding upon Canadian courts in domestic law, because they have not been incorporated into Canadian law.

\subsection{The Challenge to the Constitutionality of the Security Certificate Process}

A Charter challenge to section 40.1 of the former Immigration Act 1976 occurred in another significant immigration case. Section 40.1 outlines a process whereby a judge of the Federal Court reviews the reasonableness of a security certificate signed by the Solicitor General and the Minister of Citizenship and Immigration, declaring that a person is inadmissible for specified reasons such as espionage or terrorism. The constitutionality of the security certificate process has been challenged in the Federal Court in Ahani $^{81}$ on the basis that the process violates sections 7 (right to

${ }^{79}$ Suresh v. Canada (Minister of Citizenship and Immigration) [2002] 1 S.C.R. 3, para. 3-4.

${ }^{80}$ Notwithstanding this conclusion, the Court left a small window open for the balancing test in "exceptional circumstances", without indicating what constitutes "exceptional circumstances" (see para. 76).

${ }^{81}$ Ahani v. Canada, [1995] 3 F.C. 669 (T.D.); aff'd Ahani v. Canada, [1996] F.C.J. No. 937 (F.C.A.), leave to appeal dismissed on July 3, 1997 by the Supreme Court of Canada. 
liberty), 9 (protection against arbitrary detention) and 10(c) (right to habeas corpus) of the Canadian Charter. The Federal Court dismissed the action and concluded that section 40.1 does not violate the Canadian Charter and is constitutional. Justice McGillis of the Federal Court found that:

In enacting section 40.1 of the [former] Immigration Act, Parliament created a mechanism for the expeditious review by an independent judicial arbiter of the reasonableness of the decision of two separate ministers to issue a certificate that a person, other than a Canadian citizen or permanent resident, is a member of an inadmissible class of persons for various specified reasons, including terrorism. ${ }^{82}$

Justice McGillis dealt with the issue of delay of the reasonableness hearing by the person named in the certificate in the following terms:

In the event that the named person fails to avail himself of the opportunity to be heard within a reasonable period of time, as occurred in this case, the designated judge should proceed to determine the reasonableness of the certificate on the basis of the evidence and information available. Indeed the fact that Parliament clearly intended these proceedings to be conducted expeditiously requires the designated judge to proceed in this fashion. ${ }^{83}$

Finally, the argument on detention was rejected by the Judge. A person named in a certificate does not have the right to apply for release from custody, in the same manner as a person accused of serious offences under the Canadian criminal law. The Federal Court concluded that the scope of the principles of fundamental justice, found in section 7 of the Charter, applicable in proceedings under the security certificate process must be analysed in the context of immigration principles and policies and not according to criminal law standards:

[A] review of the provisions of section 40.1 of the Immigration Act and its legislative purpose as expressed in section 38.1 confirms that the proceedings are to be conducted expeditiously, with the concomitant expectation that the detention of the person will not be lengthy. [...] Having considered the detention requirement in section 40.1 of the Immigration Act in the immigration context, I am satisfied that the principles of fundamental justice do not require Parliament to create a procedure providing for the pre-determination release of the person, as was submitted by counsel for the plaintiff. ${ }^{84}$

In brief, the Federal Court confirmed the constitutionality of security certificates (former section 40.1, now section 77 of IRPA). To this date, this is the only caselaw where the Courts analyzed and concluded on the constitutionality of the security certificate. With IRPA, it will be interesting to see which trend the Courts will take.

${ }^{82}$ Ahani v. Canada, [1995] 3 F.C. 669, at p. 676.

${ }^{83}$ Ahani v. Canada, [1995] 3 F.C. 669, at p. 679.

${ }^{84}$ Ahani v. Canada, [1995] 3 F.C. 669, at p. 692. 


\section{CONCLUSION}

One difficult aspect addressed in this paper is the strong preoccupation of States towards security that influences the status of foreign nationals, despite the recognition of fundamental rights for all in Canada. The solution definitely rests in a balancing act of the State's security concerns with their obligation to respect the fundamental rights of migrants. The principle of territorial sovereignty cannot justify unlimited violations of rights and freedoms that are based on nationality. In other words, territorial sovereignty has to be conceived in a way that is compatible with existing mechanisms and structures of the international and national human rights system. Therefore, it is essential to recognize and to clarify the rights of non-citizens in the state's sovereignty context. Unfortunately, too often, for most politicians as for public opinion in these troubled times, "laws that arouse deep concern about civil liberties when applied to citizens are standard fare in the immigration context" ${ }^{85}$ This leading thought needs to be changed in order to maintain equal treatment between citizens and non-citizens.

There are only exceptional circumstances where fundamental rights may be suspended for a limited period of time. Derogations are allowed in some international treaties. The International Covenant on Civil and Political Rights, the European Convention on Human Rights and the American Convention on Human Rights additionally include derogation clauses allowing many of the rights protected to be derogated from in exceptional circumstances. ${ }^{86}$ In the International Covenant on Civil and Political Rights and the European Convention on Human Rights, derogation requires an officially proclaimed "public emergency" that "threatens the life of the nation". Although none of the human rights instruments or treaty monitoring bodies has developed a catalogue of the situations that qualify as a "public emergency", this was intended by the drafters to be an extremely difficult burden to meet.

Article 4 of the International Covenant on Civil and Political Rights requires indeed that any derogation be applied (1) only "to the extent strictly required by the exigencies of the situation", (2) consistent with the State's other obligations under international law, and (3) without discrimination on protected grounds. The Human Rights Committee's approach to State reports has also indicated that it believes that derogation under article 4 must be temporary, subject to some sort of parliamentary and judicial control, and responsive to an apparent, violent situation that cannot otherwise be controlled, above and beyond mere social unrest. ${ }^{87}$ In conclusion, even in situations threatening the life of the nation, a State must still demonstrate that any

\footnotetext{
${ }^{85}$ Audrey Macklin, "The Application of International Human Rights Law by Administrative DecisionMakers", in: Stephen G. Coughlan, Dean Dawn Russell, Citizenship and Citizen Participation in the Administration of Justice. Citoyenneté et participation à l'administration de la justice, Canadian Institute for the Administration of Justice / Institut canadien d'administration de la justice, Montréal: Éditions Thémis, 2002.

${ }^{86} 1966$ International Covenant on Civil and Political Rights, art. 4; 1950 European Convention on Human Rights, art. 15; 1969 American Convention on Human Rights, art. 27.

${ }^{87}$ Susan Martin, David Fisher, Andrew Schoenholtz. 2003. "Migration and Security in International Law", in: Alex Aleinikoff \& Vincent Chetail (eds.), Migration and International Legal Norms. The Hague: T.M.C. Anser Press, 2003, at p. 98.
} 
derogation of a particular right is justified in scope and duration by the specific circumstances it is facing.

The non-discrimination provisions are not subject to specific clawbacks for reasons of security, and derogation clauses prohibit a suspension of rights in a discriminatory manner. However, according to the general doctrine of non-discrimination which has emerged in the case law of the human rights treaty bodies, differentiation is permitted if it is based on "reasonable and objective criteria" and if the discriminatory means are "proportional to the reasonable end". In other words, differential treatment is permissible where the distinction is made pursuant to a legitimate aim, has an objective justification, and reasonable proportionality exists between the means employed and the aims sought to be realized. Otherwise, the differentiation constitutes discrimination and is illegal. ${ }^{88}$ It should be noted, however, that the equality principle mandates that migrants never be deprived of basic protections of physical security and fair trial: selective denial of those protections would indeed never be reasonable or proportionate. ${ }^{89}$

These security concerns are only one example of a larger issue, that of a principled approach to any differential treatment between nationals and foreigners. The standard against discrimination has not yet been consistently applied to impose demanding requirements in evaluating States' grounds for admission and expulsion. This might change in the future.

The Committee on the Elimination of Racial Discrimination's General Recommendation 30 (August 2004), on "Discrimination against non-citizens", clarifies general principles for responsibilities of States parties to the Convention vis-à-vis non-citizens and deals in particular with issues of protection against hate speech and racial violence, administration of justice, expulsion and deportation of non-citizens, economic, social and cultural rights. It recommends that States parties "ensure that any measures taken in the fight against terrorism do not discriminate, in purpose or effect, on the grounds of race, colour, descent, or national or ethnic origin and that non-citizens are not subjected to racial or ethnic profiling or stereotyping". It also stipulates: "Under the Convention, differential treatment based on citizenship or immigration status will constitute discrimination if the criteria for such differentiation, judged in the light of the objectives and purposes of the Convention, are not applied pursuant to a legitimate aim, and are not proportional to the achievement of this aim". ${ }^{90}$ It is possible, thus, to provide some restrictions on State's actions in the immigration realm by imposing on States the following general guidance:

${ }^{88}$ Joan Fitzpatrick, "The Human Rights of Migrants", in: Alex Aleinikoff \& Vincent Chetail (eds.), Migration and International Legal Norms. The Hague: T.M.C. Anser Press, 2003; Susan Martin, David Fisher, Andrew Schoenholtz. 2003. "Migration and Security in International Law", in: Alex Aleinikoff \& Vincent Chetail (eds.), Migration and International Legal Norms. The Hague: T.M.C. Anser Press, 2003; Clark, Tom, Jan Niessan, "Equality Rights and Non-Citizens in Europe and America: The Promise, the Practice and Some Remaining Issues" (1998) Netherlands Quarterly of Human Rights 17: 14.

${ }^{89}$ U.N. Human Rights Committee, General Comment 15: The Position of Aliens under the Covenant, 1986, http://www.unhchr.ch/tbs/doc.nsf/(Symbol)/bc561aa81bc5d86ec12563ed004aaa1b?Opendocument; Joan Fitzpatrick, "The Human Rights of Migrants", in: Alex Aleinikoff \& Vincent Chetail (eds.), Migration and International Legal Norms. The Hague: T.M.C. Anser Press, 2003.

${ }^{90}$ U.N. Committee on the Elimination of Racial Discrimination, General Recommendation 30: Discrimination against Non-citizens, U.N. Doc. CERD/C/64/Misc.11/rev.3 (2004). 
1. There is no possible differentiation between citizens and non-citizens regarding basic protections for physical security and fair trial.

2. A differentiation between citizens and non-citizens is legal if a State can make out a "reasonable and objective case" that differing treatment of applicants of a particular national origin is required for its security. ${ }^{91}$

This, of course, implies some supervision by the national courts and the international committees. In Canada, most of the new security measures introduced since 2001 have not yet been put to the test of a constitutional challenge. No doubt they all will. We can only hope that the Courts will take these criteria as a premise to their analysis and require that Canadian authorities systematically justify the differentiation between nationals and foreigners as regards recourses and remedies against decisions susceptible to deeply affect their rights and freedoms.

${ }^{91}$ Susan Martin, David Fisher, Andrew Schoenholtz. 2003. "Migration and Security in International Law", in: Alex Aleinikoff \& Vincent Chetail (eds.), Migration and International Legal Norms. The Hague: T.M.C. Anser Press, 2003. 